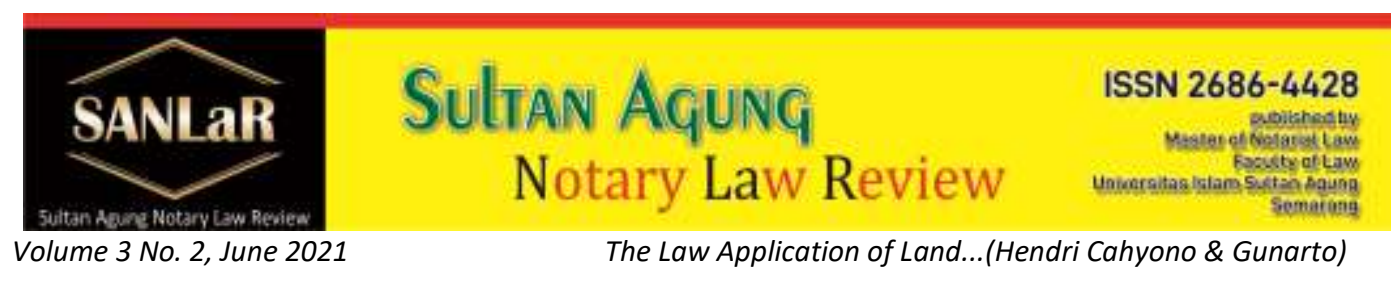

\title{
The Law Application of Land Procurement for Development in Public Interest
}

\author{
Hendri Cahyono*) and Gunarto**) \\ *) Faculty of Law, Universitas Islam Sultan Agung (UNISSULA) Semarang, E-mail: \\ naranaruto2014@gmail.com \\ *) Faculty of Law, Universitas Islam Sultan Agung (UNISSULA) Semarang, E-mail: \\ gunarto@unissula.ac.id
}

\begin{abstract}
Implementation of the application of Article 35 of Act No. 2 of 2012 concerning Land Acquisition for the Development of Toll Roads in the Public Interest. The value of compensation based on the results of the Appraiser's assessment becomes the basis for deliberation to determine compensation. In Article 35 of Act No. 2 of 2012 it is stated that if in the case of certain land parcels that are affected by land acquisition there are remnants that can no longer be functioned according to their designation and use, the entitled Party may request a complete replacement of the parcel of land. What is meant by "no longer able to function" is a parcel of land that can no longer be used according to its original designation and use, for example a residential house that is divided so that some of it cannot be used as a residential house. The objectives of this research are as follows: 1) To examine the implementation of the application of Article 35 of Act No. 2 of 2012 concerning Land Procurement for the Development of Toll Roads in the Public Interest. 2) Knowing the problems faced in the implementation of the application of article 35 of Act No. 2 of 2012 concerning Land Procurement for the Development of the Public Interest of Toll Roads. 3) Assessing the legal impact of the implementation of article 35 of Act No. 2 of 2012 concerning Land Procurement for the Development of Toll Road Public Interest. The approach method in this writing uses a doctrinal method or what is called normative legal research and qualitative descriptive analysis, namely by aligning and describing the real situation. By answering the main problems in this journal research, namely 1) How to implement article 35 of Act No. 2 of 2012 concerning Land Acquisition for the Development of Toll Road Public Interest. 2) What are the problems faced in the implementation of article 35 of Act No. 2 of 2012 concerning Land Procurement for the Development of Toll Road Public Interest. 3) What are the legal implications of the implementation of Article 35 of Act No. 2 of 2012 concerning Land Acquisition for the Development of Toll Roads in the Public Interest.
\end{abstract}

Keywords: Application; Land Procurement; Public Interest. 


\section{Introduction}

The international community recognizes Indonesia as the largest archipelagic country in the world. However, we have not managed it and we have processed it significantly," he said. ${ }^{1}$ This is because Allah SWT has blessed Indonesia with several thousand islands that stretch across various archipelagos with various abundant natural resources. These resources if managed and utilized properly can certainly be a means to achieve the goals of the Indonesian nation. In order to realize the ideals of the nation, the government issued a policy through the Nawacita program by carrying out infrastructure developments in various regions. Starting from the construction of dams, reservoirs, power plants, ports, airports, toll roads and so on. In terms of land transportation, the government has launched various toll road developments. One example is the construction of the Trans Java toll road. It is hoped that the construction of the Trans Java Toll Road can accelerate and facilitate the wheels of the Indonesian economy. This development is not easy, where obstacles arise in its implementation.

The biggest obstacle is related to the limited land owned by the government. So that it is necessary to acquire land both from government-owned land and from land owned by the people in order to meet the need for land for the development of the public interest. This is also not easy, because it will certainly cause problems. It of land acquisition is very vulnerable in handling, because it involves the livelihood of many people, when viewed from the government's need for land for development purposes, it is understandable that the available state land is very limited, therefore the only way that can be taken is by The mechanism for land acquisition for the public interest will certainly not be separated from proper and fair compensation, after the appointment of the location, it is necessary to carry out an inventory and identification of all matters regarding land, both regarding the control, use, and utilization of land needed to fulfill land needs. ${ }^{2}$

To overcome these problems, government policies have been issued in the context of efforts to acquire land for the public interest. Starting from Presidential Decree 65 of 2006 concerning Land Procurement for Implementation of Development in the Public Interest which is a refinement of Presidential Decree No. 36 of 2005 concerning Land Acquisition for Development Implementation for the Public Interest, then refined again with the issuance of

\footnotetext{
${ }^{1}$ Cicip Sutardjo, Sharif Menteri Kelautan dan Perikanan,Pembukaan acara Laut Indonesia dan Industri Perikanan Expo 2012 di Parkir Timur Senayan, Kamis (06/09/12) cited from https://finance.detik.com/berita-ekonomi-bisnis/d-2009877/cicip-sutardjo-dunia-akui-indonesianegara-kepulauan-terbesar

${ }^{2}$ Cahyono Hendri, 2018 Tinjauan Yuridis Konsinyasi Ganti Rugi Tana Untuk Kepentingan Umum (Studi Putusan Pengadilan Negeri Kabupaten Boyolali Nomor 92/Pdt.P/2016/PN.Bi), Thesis. Not published.
} 
Presidential Regulation 71 of 2012 concerning the Implementation of Land Procurement for Development in the Public Interest. However, in reality, the Government feels that these efforts are not optimal. So that a policy was issued in the form of Law of the Republic of Indonesia Number 2 of 2012 concerning Land Procurement for Public Interest. liberate community land, ${ }^{3}$ Based on this description, the author will conduct research with the main problems, namely one How is the implementation of article 35 of Act No. 2 of 2012 concerning Land Acquisition for the Development of the Public Interest of Toll Roads, what are the problems faced in the implementation of article 35 of Act No. 2 of 2012 concerning Land Acquisition for Development Public Interests of Toll Roads, three what are the legal implications Implementation of the application of Article 35 of Act No. 2 of 2012 concerning Land Acquisition for the Development of Toll Roads Public Interests

\section{Research Methods}

This research uses a type of doctrinal research or is called normative legal research. Doctrinal law research is research conducted by examining library materials or secondary data consisting of primary legal materials, secondary legal materials. The nature of this legal research used by the author includes descriptive research that examines the truth of the existence or absence of a fact caused by a certain factor, legal research is carried out to produce arguments in solving the problems at hand. The approaches used in legal research are the legal approach (statue approach), case approach, historical approach, comparative approach, and conceptual approach.

The purpose of this research is first to mto examine the implementation of the implementation of Article 35 of Act No. 2 of 2012 concerning Land Acquisition for the Development of the Public Interest of Toll Roads, secondly to find out the problems encountered in the implementation of the application of Article 35 of Act No. 2 of 2012 concerning Land Acquisition for Development of the Public Interest of Toll Roads, the third is to examine the legal impact of the implementation of Article 35 of Act No. 2 of 2012 concerning Land Acquisition for the Development of the Public Interest of Toll Roads.

\section{Result and Discussion}

3.1. Implementation of the application of article 35 of Act No. 2 of 2012 concerning Land Procurement for the Development of Toll Roads in the Public Interest

\footnotetext{
${ }^{3}$ Adrian Sutedi, Implementasi Prinsip Kepentingan Umum Dalam Pengadaan Tanah Untuk Pembangunan, Ed. 1, ed. 2 (Jakarta: Sinar Grafika, 2008), p. 45
} 
The transfer of land rights to the agency that requires the land is carried out by providing Compensation whose value is determined when the value of the announcement of the location determination is made. The value of the announcement of the location determination is the Appraiser in determining the Compensation based on the value of the Land Procurement Object on the date of the announcement of the location determination. The value of compensation based on the results of the Appraiser's assessment becomes the basis for deliberation to determine compensation. In Article 35 of Act No. 2 of 2012 it is stated that if in the case of certain land parcels that are affected by land acquisition there are remnants that can no longer be functioned according to their designation and use, the entitled Party may request a complete replacement of the parcel of land. What is meant by "no longer able to function" is a parcel of land that can no longer be used according to its original designation and use, for example a residential house which is divided so that part of it cannot be used as a residential house. In this regard, the party who controls/owns the land may ask for Compensation for the entire amount.In accordance with Act No. 2 of 2012, Land Procurement for Public Interest is carried out through the following stages:

\section{Planning;}

Land Procurement Planning for Public Interest is based on the Regional Spatial Plan and development priorities listed in the Medium Term Development Plan, Strategic Plan, Government Work Plan of the relevant Agency. ${ }^{4}$ Planning documents are determined by the agency that requires land and submitted to the Provincial Government at least containing: ${ }^{5}$

a. the aims and objectives of the development plan;

b. conformity with the Regional Spatial Planning and National and Regional Development Plans;

c. land location;

d. the required land area;

e. general description of land status;

f. estimated time of implementation of Land Procurement;

g. estimated timeframe for development implementation;

h. estimated land value; and

i. budget plan

2. Preparation;

${ }^{4}$ Article 14 paragraph (2) of Act No. 2 of 2012

${ }^{5}$ Article 14 paragraph (2) of Act No. 2 of 2012 
Agencies requiring land together with the provincial government based on the Land Procurement planning document carry out ${ }^{6}$ :

a. notification of development plans;

Notification of the development plan is submitted to the community at the planned development location for the Public Interest, either directly or indirectly.

b. initial data collection on the location of the development plan;

Initial data collection on the location of the development plan includes the initial data collection activities of the Entitled Parties and Land Procurement Objects carried out within a maximum of 30 (thirty) working days from the notification of the development plan. The results of the initial data collection on the location of the development plan are used as data for the implementation of the Public Consultation on the development plan.

c. Public Consultation on development plans.

Public Consultation on the development plan is carried out to obtain agreement on the location of the development plan from the Entitled Party and the affected community and is carried out at the location of the Public Interest development plan or at the agreed place.

The agreement is stated in the form of a minutes of agreement. On the basis of the agreement, the agency requiring the land shall submit an application for the determination of the location to the governor. The Governor determines the location within a maximum period of 14 (fourteen) working days from the receipt of the application for determination by the Agency that requires land. The Public Consultation on the development plan is carried out within a maximum period of 60 (sixty) working days, and if within 60 (sixty) working days of the implementation of the Public Consultation on the development plan there are parties who object to the planned development location, a Public Consultation shall be held with the relevant parties objected no later than 30 (thirty) working days.

3. Implementation of the Agency that requires land submits the implementation of Land Procurement to the Land Agency. Implementation of Land Procurement includes:

${ }^{6}$ Article 16 - Article 19 of Act No. 2 of 2012 
a. inventory and identification of control, ownership, use, and utilization of land, which includes: ${ }^{7}$

1) measurement and mapping of plots per plot of land; and

2) data collection of the Entitled Party and the Land Procurement Object The results of the announcement or verification and improvement shall be determined by the Land Agency and subsequently become the basis for determining the Entitled Party in granting Compensation.

b. assessment of Compensation;

The Land Agency determines and announces the Appraiser in accordance with the provisions of the legislation to carry out the assessment of the Land Procurement Object. Assessment of the amount of Compensation by the Appraiser is carried out field by parcel of land, including: ${ }^{8}$

1) land;

2) above ground and underground spaces;

3) building;

4) plants;

5) objects related to land; and/or

6) other losses that can be assessed.

c. deliberation on the determination of Compensation;

The Land Agency shall hold deliberation with the Entitled Party within a maximum period of 30 (thirty) working days after the results of the appraisal from the Appraiser are submitted to the Land Agency to determine the form and/or amount of Compensation based on the results of the Compensation assessment. The results of the agreement in the deliberation become the basis for the provision of Compensation to the Entitled Party which is contained in the minutes of the agreement. ${ }^{9}$

d. giving compensation

${ }^{7}$ Article 28 of Act No. 2 of 2012

${ }^{8}$ Article 33 of Act No. 2 of 2012

${ }^{9}$ Article 37 of Act No. 2 of 2012 
Compensation for Land Procurement Objects is given directly to the Entitled Party and can be given in the form of: ${ }^{10}$

1) money;

2) replacement land;

3) resettlement;

4) share ownership; or

5) other forms agreed by both parties.

e. release of agency land.

Article 45 of Act No. 2 of 2012 states that the release of Land Procurement Objects for Public Interest owned by the government is carried out in accordance with the provisions of the laws and regulations governing the management of state/regional property. The release of Land Procurement Objects for Public Interest controlled by the government or controlled/owned by State-Owned Enterprises/Regional-Owned Enterprises is carried out based on Act No. 2 of 2012. In Article 46 of Act No. 2 of 2012 Release of Institutional Land Procurement Objects is not given Replace Losses, except:

1) Land Procurement Objects that have been built are buildings that are used actively for the implementation of government tasks. Compensation is given in the form of land and/or buildings or relocation.

2) Land Procurement Objects owned/controlled by State-Owned Enterprises/Regional Owned Enterprises. Compensation is given in the form of money, replacement land, resettlement, share ownership or other forms agreed by both parties.

3) Village treasury Land Procurement Object. Compensation is given in the form of land and/or buildings or relocation.

4. Submission of results.

Article 48 of Act No. 2 of 2012 states that the Land Agency shall submit the results of Land Procurement to the Agency that requires land after:

a. the provision of Compensation to the Entitled Party and the Waiver of Rights have been carried out; and/or

${ }^{10}$ Article 36 of Act No. 2 of 2012 
b. compensation has been deposited in the district court.

3.2. Problems encountered in the implementation of article 35 of Act No. 2 of 2012 concerning Land Procurement for the Development of Toll Road Public Interest

The problems that are usually faced by Land owners who receive the results of the appraisal team's assessment can actually be done directly signminutes of agreement on the value of land compensation. However, if the land owner is still in doubt, and is still researching the land area, he can ask the committee directly. If the land owner does not agree, he can submit an objection with a grace period of 14 days. However, landowners affected by the toll road project up to this second deliberative event sometimes still object to the issue of price and payment rules. If we look at the principle of land acquisition for the public interest based on the explanation of Article 2 of Act No. 2 of 2012 concerning Land Procurement for Development in the Public Interest: "Land procurement for the public interest is carried out based on the principles: humanity, justice, benefit, certainty, openness, agreement, inclusion, well-being, sustainability and harmony".

3.3. Legal impact Implementation of the implementation of Article 35 of Act No. 2 of 2012 concerning Land Acquisition for the Development of Toll Roads in the Public Interest

The regulation of land acquisition for the public interest in Indonesia prior to the enactment of Act No. 2 of 2012 concerning Land Procurement for Development for Public Interest is regulated in Presidential Regulation of the Republic of Indonesia Number 65 of 2006 concerning Amendments to Presidential Regulation Number 36 of 2005 concerning Land Acquisition for Development Implementation for the Public Interest. In practice, it is not an easy matter to achieve justice in the provision of compensation because problems related to land are sensitive issues that concern the people. Good communication is needed between the government and the community so that there are no problems that can hinder the implementation of development.

The view of justice in national law is based on the basis of the state, namely Pancasila, in which the fifth precept reads social justice for all Indonesian people. Pancasila as the basis of the state or the philosophy of the state until now has been maintained and is important for Indonesia. In the concept of social justice, there is an acknowledgment of human dignity who has the same rights that are human. Social justice is a condition in which the wealth and resources of a country are distributed fairly to all people. This is different from the concept of legal justice which is usually enforced through a legal process. Social justice is not 
just talking about justice in the sense of upholding laws and regulations, but talking more broadly about the rights of citizens in a country.

The government must be careful in determining the amount of compensation to be given to communities affected by development projects. The problem that is often encountered in land acquisition is the value of compensation. The land price is assessed by the government appraisal team by referring to the Sales Value of Tax Objects in accordance with Article 15 Paragraph (1) of Presidential Regulation Number 65 of 2006 which states that the basis for calculating the amount of compensation is based on the Sales Value of Tax Objects (NJOP) or the real value by taking into account Sales Value of Tax Objects for the current year based on the assessment of the Land Price Appraisal Agency/Team appointed by the committee Meanwhile, the selling value of buildings is estimated by the regional apparatus responsible for building and the selling value of the plants is estimated by the regional apparatus responsible for agriculture.

\section{Closing}

The transfer of land rights to the agency that requires the land is carried out by providing Compensation whose value is determined when the value of the announcement of the location determination is made. The value of the announcement of the location determination is the Appraiser in determining the Compensation based on the value of the Land Procurement Object on the date of the announcement of the location determination. The value of compensation based on the results of the Appraiser's assessment becomes the basis for deliberation to determine compensation. In Article 35 of Act No. 2 of 2012 it is stated that if in the case of certain land parcels that are affected by land acquisition there are remnants that can no longer be functioned according to their designation and use, the entitled Party may request a complete replacement of the parcel of land. What is meant by "no longer able to function" is a parcel of land that can no longer be used according to its original designation and use, for example a residential house which is divided so that part of it cannot be used as a residential house. In this regard, the party who controls/owns the land may ask for Compensation for the entire amount. The view of justice in national law is based on the basis of the state, namely Pancasila, in which the fifth precept reads social justice for all Indonesian people. Pancasila as the basis of the state or state philosophy until now has been maintained and is important for Indonesia. In the concept of social justice, there is an acknowledgment of human dignity who has the same rights that are human. Social justice is a condition in which the wealth and resources of a country are distributed fairly to all people. This is different from the concept of legal justice which is usually enforced through a legal process. 


\section{References}

Journals:

[1] Aprizka Mandauwing, Ocky. 2011. Pelepasan Hak Atas Tanah Untuk Pembangunan Jalan Tol Semarang-Ungaran Dilihat Dari Peraturan Presiden Republik Indonesia Nomor 36 Tahun 2005. Skripsi Universitas Negeri Semarang.

[2] Cahyono Hendri, 2018 Tinjauan Yuridis Konsinyasi Ganti Rugi Tana Untuk Kepentingan Umum ( Studi Putusan Pengadilan Negeri Kabupaten Boyolali Nomor 92/Pdt.P/2016/PN.Bi), not published

[3] Cicip Sutardjo, Sharif Menteri Kelautan dan Perikanan ,Pembukaan acara Laut Indonesia dan Industri Perikanan Expo 2012 di Parkir Timur Senayan, Kamis (06/09/12) dikutip dari https://finance.detik.com/berita-ekonomibisnis/d-2009877/cicip-sutardjo-dunia-akui-indonesia-negara-kepulauanterbesar

[4] Erwin Nugroho Suddin,Suparnyo Suparnyo,Subarkah Subarkah Model Pengadaan Tanah Untuk Pembangunan Jalan Tol (Praktik Baik/Best Practice Pembebasan Tanah Untuk Jalan Tol Trans Jawa Ruas Solo Mantingan I Di Kabupaten Karanganyar) Vol 19, No 2 (2018) $>$ Suddin

[5] Lova Evi Fajriantina Pengadaan Tanah Dalam Pembangunan Infrastruktur Jalan Tol Oleh Badan Usaha Milik Negara (Persero) Jurnal Hukum,Magister IImu Hukum Kenotariatan 2016

[6] Waskito Jati, Luthfi. 2012. Proses Pengadaan Tanah Untuk Keperluan Pembangunan Jalan di Kabupaten Semarang. Jurnal Universita Negeri Semarang.

Book:

[1] Adrian Sutedi, , 2008, Implementasi Prinsip Kepentingan Umum Dalam Pengadaan Tanah Untuk Pembangunan, Ed. 1, Jakarta: Sinar Grafika

[2] Ali, Zainuddin. 2014. Metode Penelitian Hukum. Jakarta: Sinar Grafika.

[3] Amiruddin, Zainal Asikin. 2010. Pengantar Metode Penelitian Hukum. Jakarta: Rajawali Pers.

[4] Arikunto, Suharsimin. 2006. Prosedur Penelitian. Jakarta: PT. Rineka Cipta.

[5] Asri, Benyamin, Thabrani Asri. 1987. Tanya Jawab Pokok-Pokok Hukum Perdata dan Hukum Agraria. Bandung: CV. ARMICO.

[6] B. Miles, Matthew, A. Michael Huberman. 2007. Analisis Data Kualitatif. Jakarta: Universitas Indonesia. 
[7] Danim, Sudarwan. 2002. Menjadi Peneliti Kualitatif. Bandung: CV. Pustaka Setia.

[8] Halim, Ridwan. 1985. Hukum Agraria Dalam Tanya Jawab. Jakarta: Ghalia Indonesia.

[9] Harsono, Boedi. 1971. Sedjarah Penjusunan isi dan pelaksnaanja Hukum Agraria Indonesi. Jakarta: Djambatan. . 2008. Hukum Agraria Indonesia. Jakarta: Djambatan.

[10] Iskandar, Mudakir. 2010. Pembebasan Tanah Untuk Pembangunan Kepentingan Umum. Jakarta: Jala Permata Aksara.

[11] Kartono, Kartini. 1996. Pengantar Metodologi Riset Sosial. Bandung: Mandar Maju.

[12] Moleong, Lexy. 2007. Metodologi Penelitian Kualitatif. Bandung: PT. Remaja Rosdakarya

[13] Noor, Aslan. 2006. Konsepsi Hak Milik Atas Tanah Bagi Bangsa Indonesia. Bandung: CV Mandar Maju.

Regulation:

[1] Act No. 2 of 2012 concerning Land Procurement for Development in the Public Interest.

[2] Act No. 5 of 1960, concerning Basic Regulations on Agrarian Principles.

[3] Constitution of 1945.

Internet:

Cicip Sutardjo, Sharif Minister of Maritime Affairs and Fisheries, Opening of the Indonesian Sea and Fisheries Industry Expo 2012 at the East Parking Senayan, Thursday (06/09/12) quoted fromhttps://finance.detik.com/berita-ekonomibisnis/d-2009877/cicip-sutardjo-dunia-akui-indonesia-negara-kegununganterbesar 